\title{
Festivais esportivos varzeanos em Belo Horizonte: memória social da cultura futebolística popular
}

\author{
Varzean sports festivals in Belo Horizonte: \\ social memory of popular football culture
}

\author{
Raphael Rajão Ribeiro \\ Museu Abílio Barreto (PBH), Belo Horizonte / Brasil \\ Doutorando em História, Política e Bens Culturais, CPDOC-FGV \\ raprajao@gmail.com
}

\begin{abstract}
RESUMO: 0 artigo se propõe a discutir a realização de festivais esportivos pelos clubes de futebol de várzea de Belo Horizonte, especialmente durante o século XX. Essa forma de celebração foi característica dessa prática atlética e cultural, sendo um dos elementos centrais da conformação do calendário das agremiações amadoras até os anos 1980, a partir de quando, progressivamente, foi entrando em desuso. Por meio da memória social construída acerca da festividade, pretende-se discutir relações de reciprocidades e formas rituais que ela encerrava, de modo a compreender os significados da cerimônia para a conformação e a renovação de laços entre os seus participantes.
\end{abstract}

PalavRAS-CHAVE: Futebol amador; Ritual; Reciprocidade; Memória social.

ABSTRACT: This article propose to discuss the realization of sportive festivals by "futebol de várzea" clubs in Belo Horizonte, especially during the $20^{\text {th }}$ century. This kind of celebration was typical of this athletic and cultural practice, being one of the central elements of the amateurs associations' calendar until the 1980's. Period when, gradually, fell into disuse. Through the social memory constructed about this celebration, the paper intent discuss reciprocal relationships e ritual forms related with the festivals, in order to comprehend the meanings of this ceremony to the conformation and renovation of links between their participants.

KEYwORDS: Amateur football; Ritual; Reciprocity; Social Memory. 


\section{INTRODUÇÃo}

Em outubro de 1948, o Departamento de Futebol Amador - D. F. A., vinculado à Federação Mineira de Futebol, resolvia colocar fim às sucessivas solicitações dos clubes filiados para o adiamento de jogos pelo campeonato da entidade, as quais interferiam no andamento da competição, ao prolongar sua realização e dificultar a conciliação do calendário de partidas. A gravidade da medida era noticiada pelos jornais da época, a exemplo do Diário da Tarde:

O Diretor do Departamento de Futebol Amador, no intuito de coibir abusos dos clubes, expediu, ontem, uma nota oficial, indeferindo todos os adiamentos de jogos e desistência dos clubes do restante do campeonato oficial. Entre outros, foi indeferido o pedido do Renascença E. C., disciplinada agremiação do bairro que lhe empresta o nome e que, de comum acordo com o Barreiro, havia solicitado transferência da data de realização do jogo oficial que deveria ser programado para o proximo domingo, afim de que o primeiro pudesse realizar um festival pela passagem de seu $7^{\circ}$ aniversário de fundação. ${ }^{1}$

A mesma reportagem trazia as razões do presidente do Renascença que ponderava:

- A festa de aniversario do Renascença é uma das mais tradicionais do clube que presido. Anualmente, promovemos um festival esportivo em comemoração á data de sua fundação. Assim, recebemos com surpresa a resolução do diretor da entidade amadorista. ${ }^{2}$

Ainda segundo a reportagem, o dirigente daquele clube operário teria afirmado que:

A direção da Fábrica, diante da resolução do D. F. A., autorizou-nos a desligar o nosso clube. Todavia, nós que sempre trabalhamos pelo desenvolvimento do esporte, que sempre colaboramos com os clubes e a entidade, não pensamos em tomar tal atitude. ${ }^{3}$

\footnotetext{
${ }_{1}^{1}$ PRECIPITADA DECISÃO DO D. F. A. Diário da Tarde, 16 de outubro de 1948, p. 5.

2 PRECIPITADA DECISÃO DO D. F. A. Diário da Tarde, 16 de outubro de 1948, p. 5.

${ }^{3}$ PRECIPITADA DECISÃO DO D. F. A. Diário da Tarde, 16 de outubro de 1948, p. 5.
} 
O episódio noticiado pelo Diário da Tarde evidencia a centralidade que os festivais esportivos tinham no cotidiano das agremiações do futebol amador de Belo Horizonte. O elevado status dessa celebração também foi apontado por dezenas de informantes entrevistados para a formulação do Inventário do Futebol Amador em Belo Horizonte. ${ }^{4}$

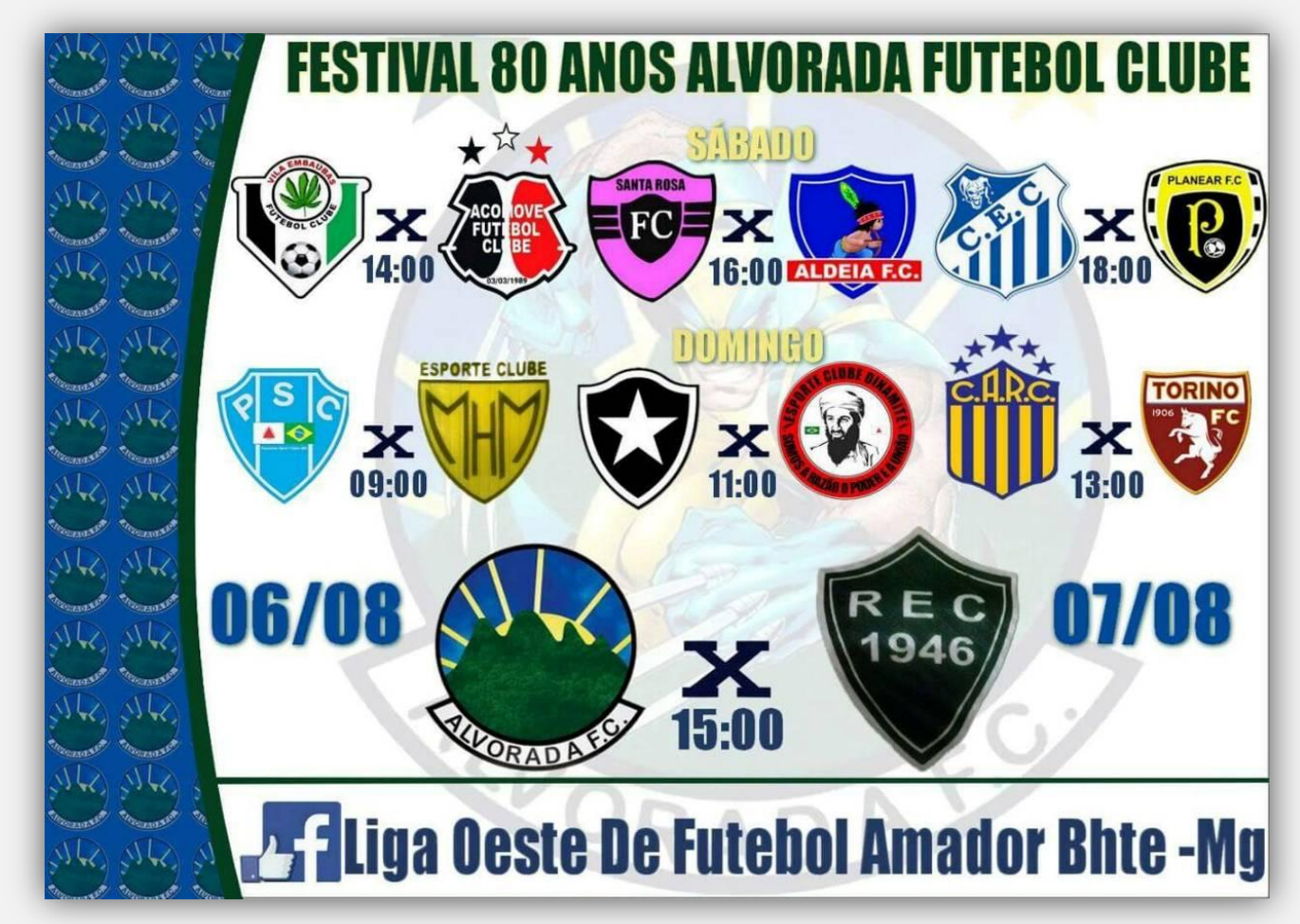

Fig. 1: Programa do festival de 80 anos do Alvorada Futebol Clube, que circulou nas listas de Whatsapp do futebol de várzea de BH. Acervo pessoal.

Foi com base nessas percepções que acompanhei, em agosto de 2016, o festival em comemoração aos 80 anos do Alvorada Futebol Clube, do bairro Nova Gameleira. Com programa de jogos que se estendia pelo sábado e pelo domingo (fig. 1), o evento que pude testemunhar em muito se afastava daquilo que me era apontado pelas fontes. Disputas que pouco mobilizavam a comunidade e provocavam baixo interesse entre os jogadores. O Alvorada, por exemplo, disputou

\footnotetext{
${ }^{4}$ O Inventário do Futebol em Belo Horizonte trata-se de projeto desenvolvido, entre 2016e 2018, pela Fundação Municipal de Cultura de Belo Horizonte, em parceria com a Secretaria Municipal de Esporte e Lazer, para produção de informação acerca dos clubes e dos campos do futebol amador da capital mineira com vistas à submissão de proposta de reconhecimento da prática como patrimônio imaterial do município, bem como levantamento de dados para elaboração de políticas públicas para o setor.
} 
a partida de fundo com time que mesclava garotos e veteranos, formação bem diferente da que eu havia visto meses antes pelo campeonato do D. F. A. Nada de patronos, rainhas, bandeirolas, alambrados apinhados de gente e diversos outros elementos que comporiam aquela cerimônia. Ainda assim, alguns ritos estavam presentes, como a entrega de troféus, o foguetório e a prestação de homenagens a pessoas ligadas ao clube, que fizeram parte de sua história que ali completava mais uma década.

Em boa parte dos relatos, o festival emerge como celebração cheia de simbolismos, evento que, no passado, era central na elaboração do calendário das equipes do futebol amador da cidade. A partir da passagem dos anos 1980 para os 1990, a cerimônia teria sido, lentamente, abandonada, de modo a despertar cada vez menos interesse nos mais jovens. Como destacou em entrevista Carlos Roberto Pimenta, o Fumê, ligado ao Pitangui, do bairro Lagoinha:

É... aquelas bandeirolas... era difícil, cercava o campo todo com aquele trem, patrono tinha que trazer uma bola. Nossa, o negócio era show de bola. Quem viu, viu... e infelizmente a meninada hoje, se você fala, você conta para um menino, eles ficam é rindo da gente... era um negócio simples, entendeu? Mas que chamava a atenção. ${ }^{5}$

Dada essa característica do fenômeno social, ou seja, uma prática em desuso, que hoje se mantém de forma esporádica e que preserva apenas parte de sua ritualística, as proposições de articulação entre História e Antropologia apresentadas por Robert Darton são especialmente inspiradoras. Como aponta o autor, a mobilização de reflexões da etnografia permite explorar as trocas simbólicas não apenas em suas relações mais diretas, que articulam o significante ao seu significado de forma óbvia, como também na multiplicidade de sentidos que cada emblema comporta, as quais são avaliadas contextualmente. ${ }^{6}$

Essas operações permitem que, a partir de evidências do passado, oriundas das mais diversas fontes, o pesquisador possa buscar a restituição dos sentidos possíveis que aquele texto, som, imagem ou gesto encerrariam. Nessa perspectiva, o presente texto se propõe a apresentar os elementos que comporiam os festivais esportivos realizados pelos clubes amadores de Belo Horizonte e articular seus

\footnotetext{
${ }^{5}$ Entrevista de Carlos Roberto "Fumê" Pimenta concedida ao autor em 13 de maio de 2016.

${ }^{6}$ Cf. DARTON. O beijo de lamourette, p. 284.
} 
significados possíveis a algumas discussões antropológicas acerca dos rituais e das trocas simbólicas.

A esse respeito, reflexão bastante útil foi apresentada por Martine Segalen no livro Ritos e rituais contemporâneos, em que revisita o debate antropológico acerca dos rituais nas sociedades tradicionais e aponta caminhos para pensá-los nos dias atuais. Para fazer essa transposição, que muitas vezes significará um alargamento da compreensão do conceito, que originalmente foi muito ligado a aspectos do sagrado e a contextos mais claramente liminares, a autora propõe a seguinte definição:

0 rito ou ritual é um conjunto de atos formalizados, expressivos, portadores de uma dimensão simbólica. 0 rito é caracterizado por uma configuração espaço-temporal específica, pelo recurso a uma série de objetos, por sistemas de linguagens e comportamentos específicos e por signos emblemáticos cujo sentido codificado constitui um dos bens comuns de um grupo.7

Ao examinar o fenômeno a partir dessa definição, a autora mostra-se capaz de apreender toda a plasticidade que encerra, observando, inclusive na duração, as transformações daquilo que a princípio soaria como tradicional e imutável. ${ }^{8}$ Nessa perspectiva, identifica diversos contextos nos quais os rituais se desenvolvem, a exemplo de festas cívicas e políticas, celebrações corporativas e eventos esportivos.

Considerando-se o elemento de plasticidade que marca celebrações coletivas carregadas de simbolismo, vale lembrar que festivais esportivos inseremse em tradição que antecede à introdução do futebol no Brasil. ${ }^{9}$ Mesmo entre os clubes tradicionais, ligados às classes altas, foi comum a promoção dessa celebração, que contava com vários ritos depois observáveis nas festividades das agremiações varzeanas.

\footnotetext{
${ }^{7}$ SEGALEN. Ritos e rituais contemporâneos, p. 31.

${ }^{8}$ SEGALEN. Ritos e rituais contemporâneos, p. 15.

${ }^{9} \mathrm{Em}$ várias cidades brasileiras, ainda no século XIX, já se testemunhavam festivais ou festas esportivas, que reuniam diversas provas, ou mesmo, diferentes modalidades em um programa que se estendia por um dia inteiro. Cf. MELO (org.) Os sports e as cidades brasileiras.
} 
Como aponta Jhonatan Souza, no caso paranaense, a inserção de partidas em festivais esportivos era o meio mais comum de prática do futebol em Curitiba até a criação da Liga, que passou a organizar o campeonato local. Realizados no Jockey Club, reuniam programação que incluía modalidades como corridas atléticas, provas ciclísticas, exibições de ginástica etc. ${ }^{10}$ Promoções parecidas foram vistas no caso belo-horizontino, com ou sem o futebol.11

A realização de festivais pelas agremiações varzeanas, nessa medida, tratase de apropriação de cerimônia que marcou a prática esportiva desde a sua introdução no país, bem como na capital mineira. Essa estrutura de celebração não era estranha a outras manifestações culturais, haja vista os festivais artísticos ou os festivais anarquistas ou operários, em geral, realizados ao ar livre, marcando uma sociabilidade moderna, a qual propunha a apropriação de áreas verdes dentro ou nas cercanias dos centros urbanos do início do século XX.

Muitos dos ritos presentes nos festivais varzeanos mimetizavam elementos daquelas celebrações que entraram em desuso a partir do ingresso dos clubes mais tradicionais no circuito competitivo, o qual veio a se configurar, mais tarde, como o futebol profissional.

\section{FESTIVAIS ESPORTIVOS NA VÁRZEA BELO-HORIZONTINA}

Os festivais esportivos realizados no meio do futebol amador em Belo Horizonte, conforme evidencia a documentação consultada e os informantes entrevistados, mantiveram estrutura mais ou menos estável entre as décadas de 1940 e 1980, sem grandes variações na sua organização. A título de exemplo, apresenta-se o programa da comemoração ao 36º aniversário do Inconfidência Esporte Clube, do bairro Concórdia (fig, 2), que traz a dinâmica básica desse tipo de celebração. A seguir, serão indicados brevemente, os elementos componentes da festividade.

\footnotetext{
${ }^{10}$ Cf. SOUZA. A "Candidatura Sportiva" e outras aproximações entre esporte e política na Curitiba da Primeira República, p. 126.

${ }^{11}$ Cf. RIBEIRO. A bola, as ruas alinhadas e a uma poeira infernal.
} 


\section{Programa}

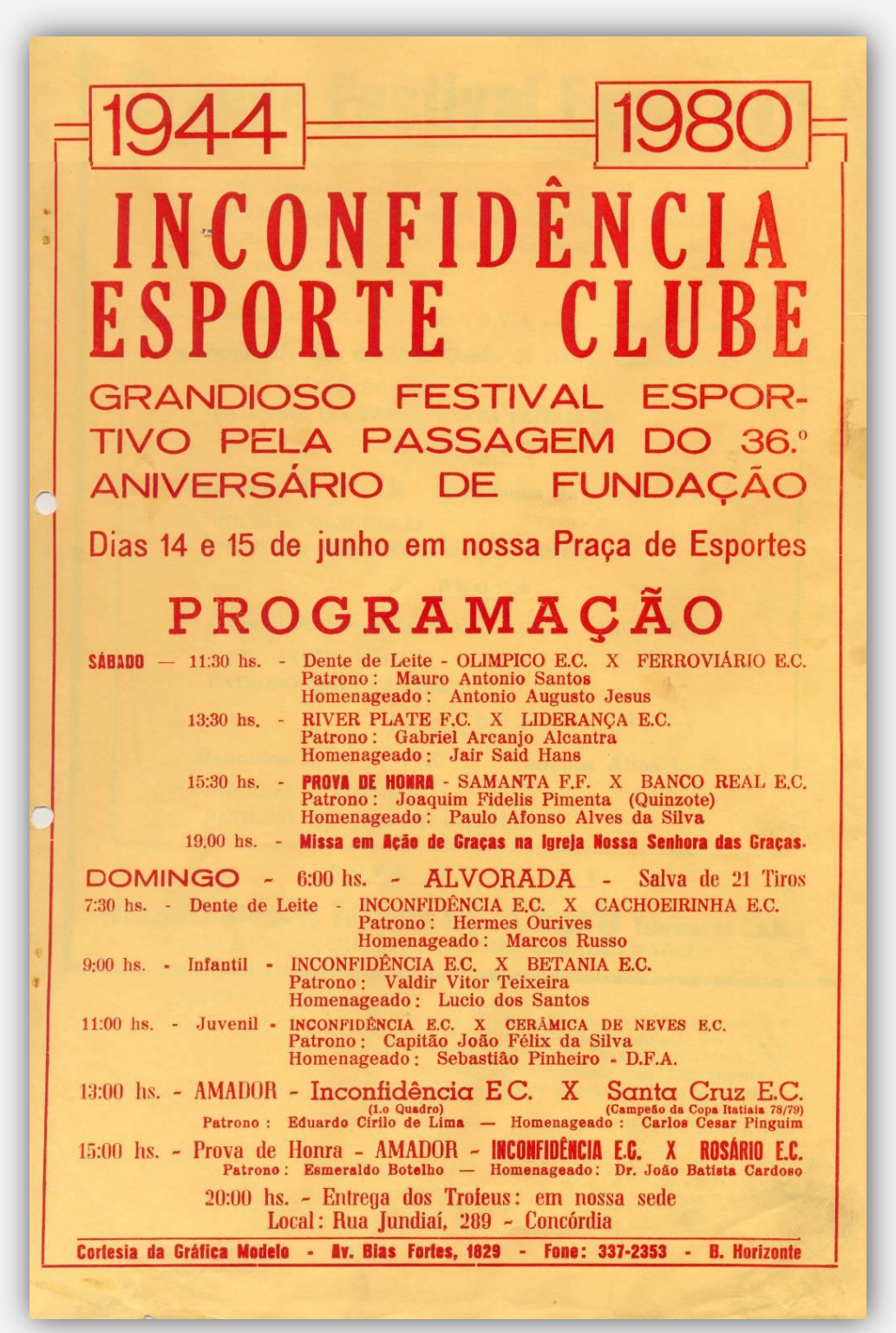

Fig. 2: Programa do festival de 36ํaniversário do Inconfidência E.C. Pasta do Inconfidência no Departamento de Futebol Amador da Capital. Acervo do Inconfidência Esporte Clube.

O núcleo dos festivais é constituído pelo programa de jogos organizados em função da celebração. Cada partida desenvolve-se independente das demais e prevê a oferta de premiação específica aos contendores, normalmente, um troféu. Os certames desenvolvem-se, em regra, ao longo do sábado e do domingo, sendo possível haver competição em apenas um dia, bem como a extensão por mais de 
um fim de semana. Fator determinante para isso é a posse do campo, que lhe dá maior ou menor flexibilidade para escolha. Associações que dependem do aluguel de um espaço podem ter de restringir a duração de sua festividade. Em sua entrevista, João "Ferrinho", ligado ao Monte Azul, do bairro Esplanada, relatou as dificuldades para promoção de seus festivais decorrentes da perda do campo até então utilizado pela entidade:

É difícil você... Você tem que alugar o campo o dia inteiro, o sábado e domingo, a gente não aguenta. É difícil demais, aí acabou tudo. A gente vai em festival agora que os outros convidam a gente, a gente vai. Mas fazer festival não fizemos mais não, como é que faz? Não tem campo, né. E você quer alugar um campo, você não consegue alugar um campo sábado e domingo o dia todo, você não consegue. Porque a maioria desses campos aí, é alugado pra outros times também sabe.12

De acordo com a quantidade de categorias que a agremiação possui, são promovidas disputas de modo a contemplar as várias faixas etárias, sendo que, normalmente, a programação se dá por ordem de importância dos jogos. Assim, as crianças tendem a ocupar os sábados pela manhã, veteranos os sábados à tarde, juvenis e juniores os domingos pela manhã e adultos as tardes de domingo. Alguns jogos podem ter a duração reduzida, dada a faixa etária dos participantes, ou como forma de permitir a realização de mais partidas ao longo do dia. $\mathrm{O}$ embate principal sempre envolve a equipe adulta principal do clube contra um convidado e é chamada Prova de Honra.

\section{Alvorada}

Mais comumente realizada nas manhãs de domingo, a alvorada trata-se da reprodução da tradicional salva de tiros realizada em ritos militares. Com a utilização de fogos de artifício, são dados 21 avisos sonoros que tem por função notificar à comunidade que se iniciam as atividades do dia principal da festividade. Os horários da alvorada variam, mas, normalmente, aconteciam às 5 ou às 6 horas da manhã. Não havia partidas na sequência, contudo, era ocasião de dar

\footnotetext{
${ }^{12}$ Entrevista de João Antônio "Ferrinho" Paranhos Leão e José Fernando "Preto" Pereira concedida ao autor em 15 de janeiro de 2017.
} 
prosseguimento aos preparativos para a celebração, que envolviam a finalização da decoração do campo de jogo.

\section{MISSA EM AÇÃO DE GRAÇAS}

Nem todos os relatos referem-se à realização de missas por ocasião dos festivais, mas era tendência que fossem celebradas missas em ação de graças, as quais normalmente aconteciam aos domingos pela manhã, antes do início do programa de partidas. Como no caso do festival do Inconfidência, ela poderia acontecer em outros horários, a exemplo do sábado à noite. Houve casos em que foi montado altar no espaço de jogo, propiciando missa campal. Dona Maria da Conceição, expresidente do Avante da Vila Nossa Senhora da Conceição no Aglomerado da Serra diz que "O festival, começava, sempre a gente pedia um padre pra celebrar a missa [...] 0 padre celebrava a missa campal, ali no (inaudível), na porta da venda ali, aí começava". ${ }^{13}$

\section{BAILE DE GALA}

Ao final do festival, era comum a realização de um baile de gala, no início da noite de domingo, podendo haver também baile na noite anterior de sábado, como previa, por exemplo, o programa do festival do Santa Maria, do Conjunto Santa Maria, realizado em 1977, em comemoração ao seu 19a aniversário (fig. 3).

Trata-se de um dos primeiros elementos dos festivais a entrar em desuso, sendo mais frequente até os anos 1960, já que para sua realização era necessário que a agremiação mantivesse sede social. Com a pressão da urbanização, muitos clubes perderam seus espaços de encontro, preservando apenas o campo. Contudo, para os que tinham um local próprio, era ocasião de promover noite dançante especial, com a contratação de conjunto musical. Amir Vimieiro, filho do fundador da Associação Atlética Popular, do bairro São Paulo, recorda-se acerca dos bailes realizados na sede da agremiação: "Tinha... no festival tinha orquestra... fora do

\footnotetext{
${ }^{13}$ Entrevista de Maria da Conceição, Eliana e Carlos Pereira concedida ao autor em 10 de março de 2017.
} 
festival era no famoso LP. É, foi muito bom. [...] ele era a conclusão do festival, né? [...] Era o baile de gala".14

O baile poderia ser ocasião para a distribuição das premiações aos vencedores da partida, bem como de coroação das rainhas e princesas do festival.

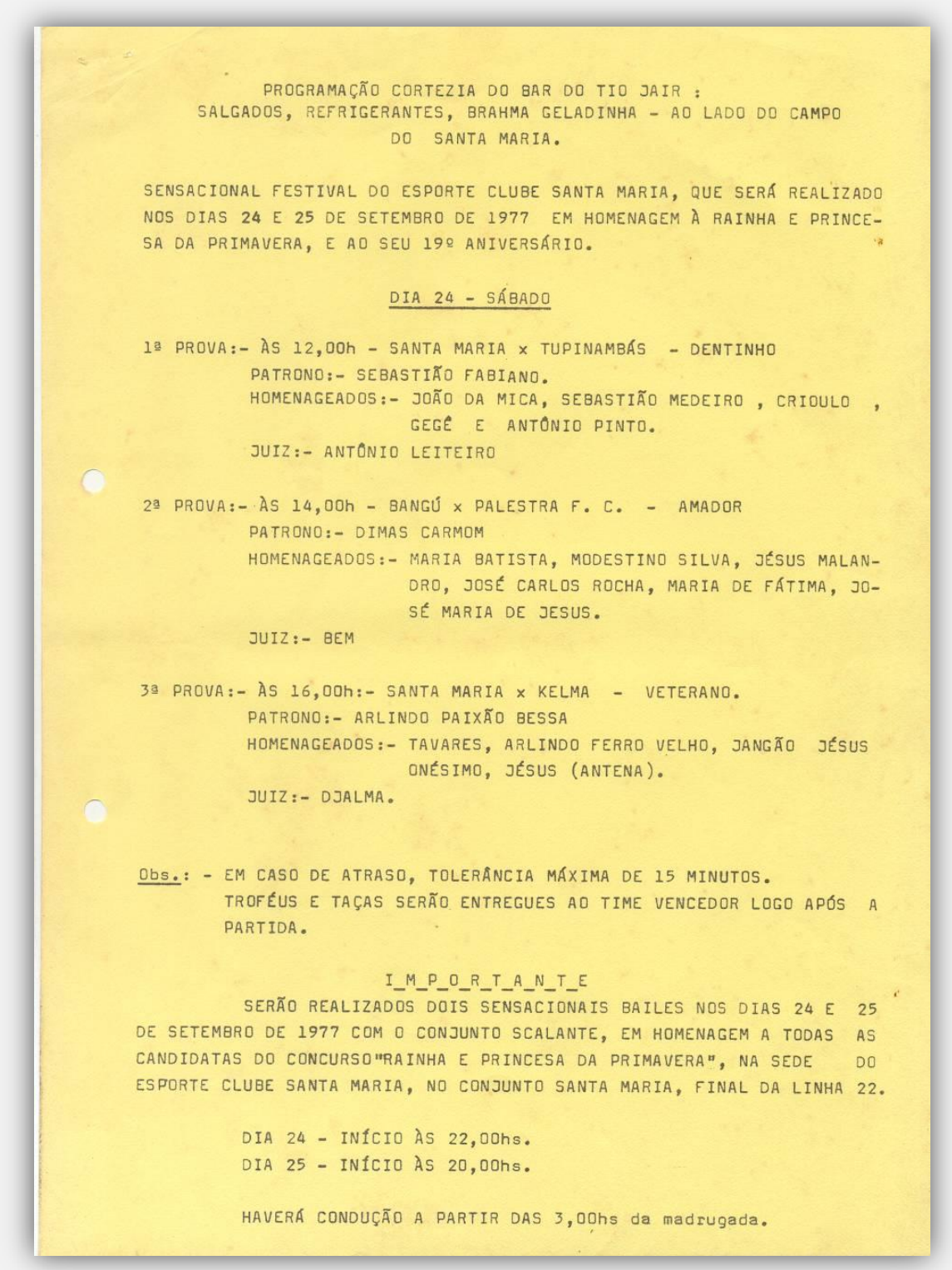

Fig. 3: Programa do festival do $19^{\circ}$ aniversário do Santa Maria Esporte Clube. Pasta do Santa Maria no Departamento de Futebol Amador da Capital. Acervo do E. C. Santa Maria.

\footnotetext{
${ }^{14}$ Entrevista de Amir Bertholdo Vimieiro e Antônio Geraldo de Carvalho concedida ao autor em 24 de abril de 2016.
} 


\section{Provas}

Cada uma das partidas ou provas, como eram chamadas, previa sequência ritual que consistia na entrada dos capitães acompanhados pelo patrono, responsável pela oferta do troféu colocado em disputa, bem como do padrinho ou madrinha da bola, que presenteava o clube com a bola do jogo, que depois seria reaproveitada pela agremiação. Como pode ser observada na imagem de festival do Suzana, do bairro homônimo, nos anos 1980 (fig. 4). Na disputa principal, a Prova de Honra, os capitães retornavam e acompanhavam a rainha do festival, como na foto do festival da Ferroviária, da Pedreira Prado Lopes, no campo do Pitangui, nos anos 1970 (fig. 5).

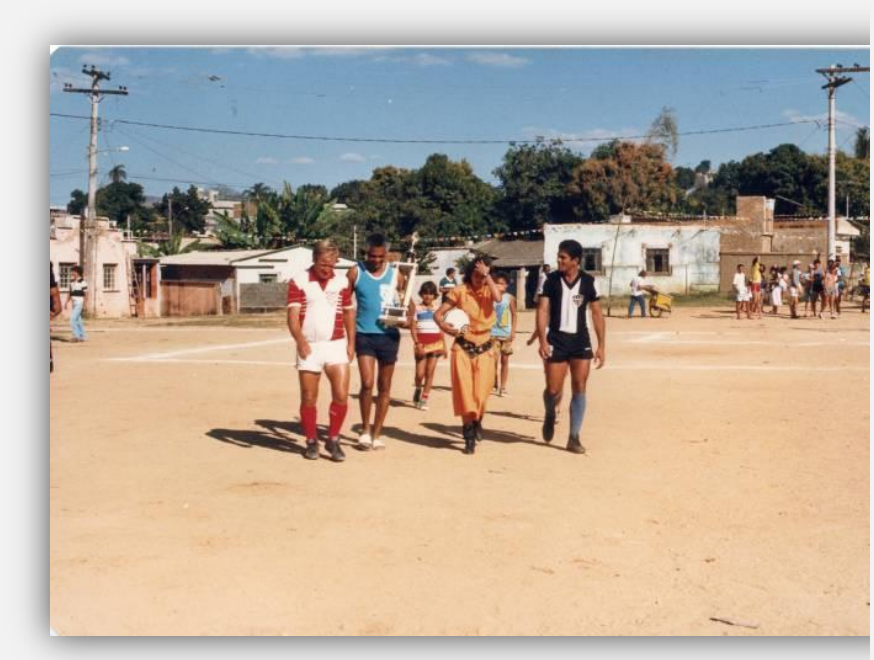

Fig. 4: Entrada em campo de capitães, patrono e madrinha da bola durante festival do Suzana, anos 1980. Acervo Antônio Jorge "ló" Silva.

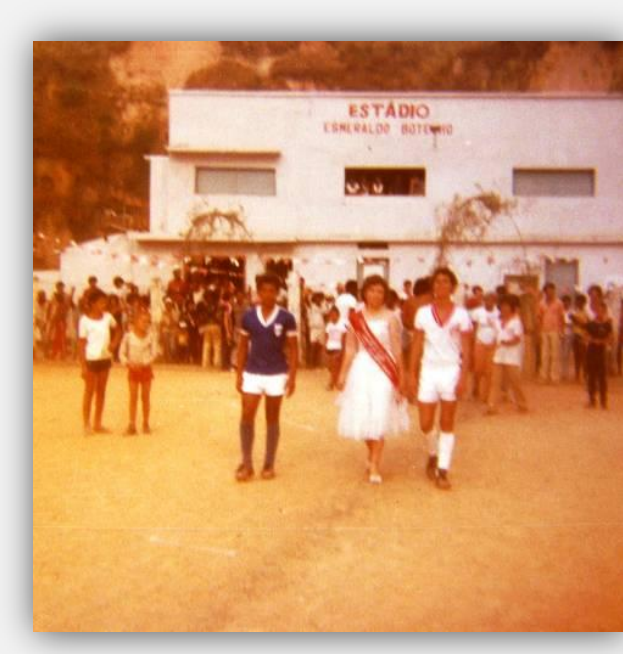

Fig. 5: Entrada de capitães e rainha em festival do Ferroviária, anos 1970. Acervo Renato Arruda.

Após a entrada em campo, havia a oferta do troféu, como relatou o expresidente do Reunidos, do bairro Alto dos Pinheiros, Jair Colen Filho, conhecido como Lu:

E então ela comparecia no dia e ela fazia um rápido discurso, o Reunidos agradecia, explica quem era aquela pessoa, ela também desejava sucesso para os que estavam jogando, dava o chute inicial, mostrava o troféu que ela estava ofertando, né? E explicava que se terminasse empatado era disputa de pênaltis, que não podia ter prorrogação por causa de horário, era disputa de pênaltis, e o vencedor levava o troféu. ${ }^{15}$

\footnotetext{
${ }^{15}$ Entrevista de Jair "Lu” Colen Filho concedida a Raphael Rajão Ribeiro em 18 de setembro de 2016.
} 
Como apontado pelo depoente, as provas, se empatadas, normalmente decidiam-se em disputas de pênaltis, já que os festivais previam sequência de jogos. Garantir que a Prova de Honra pudesse se desenrolar com luz natural, uma vez que praticamente não havia campos com refletores, era desafio para a organização da festividade. Ao final da disputa, os troféus eram entregues pelos patronos, junto ou não da rainha, conforme a partida. Eventualmente, como apontado antes, a premiação poderia ser concedida posteriormente, durante o baile.

\section{LAÇOS COMUNITÁRIOS, SUBSISTÊNCIA E RECIPROCIDADES NOS FESTIVAIS VARZEANOS}

A promoção de um festival demandava a mobilização prévia de alguns responsáveis, que passavam meses programando a atividade. Raimundo Expedido Fernandes, ex-presidente da Ferroviária da Pedreira Prado Lopes, comenta acerca dos preparativos: "Exatamente, conseguíamos cinco, seis bolas, os troféus, o material, aquela estrutura do enfeite, foguete, marcação de campo, arbitragem, era... A gente pra fazer um festival levava cinco, seis meses organizando".16

Ao longo desse processo e durante o festival, havia a articulação e a reiteração de inúmeras relações forjadas pelos clubes e por seus membros com ampla gama de atores sociais, as quais, de uma forma ou de outra, eram representadas dentro da sequência ritual da celebração. Realizados anualmente, em função do aniversário da entidade, a comemoração marcava a passagem de novo ciclo da agremiação, na qual uma multiplicidade de vínculos era reafirmada.

Para compreensão das relações que eram dramatizadas ao longo dos festivais e ali firmadas ou renovadas, as reflexões de Marcel Mauss acerca de uma economia das trocas, marcada por sistema de prestações e contraprestações, que encerram obrigações e até mesmo antagonismos e rivalidades, são, especialmente, inspiradoras. ${ }^{17}$ Como se tentará demonstrar, muitos momentos que antecediam ou que se davam durante a celebração eram carregados de sentidos de reciprocidade. A seguir, serão apontados aspectos da preparação da festividade que evidenciam parte dessas conexões.

\footnotetext{
${ }^{16}$ Entrevista de Raimundo Expedito Fernandes concedida ao autor em 20 de janeiro de 2017.

${ }^{17}$ Cf. MAUSS. Ensaio sobre a dádiva, p. 183-314.
} 


\section{CONVITE AOS TIMES}

A constituição do programa de jogos que comporia o festival era elemento fundamental para o sucesso do evento. Deveria proporcionar uma sequência de embates que fossem, ao mesmo tempo, equilibrados, de modo a tornar as partidas absorventes, no sentido evocado por Geertz, ${ }^{18}$ com a presença de equipes renomadas, bem como, reafirmar laços de proximidade com agremiações da região. A posse do campo era algo que influenciava nessas escolhas, sendo que as associações que possuíam espaço próprio tinham mais liberdade.

No caso dos clubes desprovidos de campo, uma primeira negociação já se fazia necessária, dado que, para garantir a disponibilidade do espaço de jogo durante um dia ou um fim de semana inteiro, precisam retribuir àqueles times que normalmente ocupavam os horários do lugar, com a oferta de participação na programação do festival que organizariam.

Mesmo agremiações que detinham a posse de seu espaço de jogo procuravam privilegiar aquelas equipes que mantinham horários regulares em seu campo, uma vez que elas contribuíam para a manutenção do lugar ao longo de todo o ano, ao pagarem ajuda de custo. A honra de participar do festival e poder propor a programação de uma das partidas que comporiam a celebração representava reconhecimento que reforçava a relação estabelecida. Da mesma forma, o convite a uma associação gerava a expectativa de reciprocidade, com futuro chamado para tomar parte na comemoração do visitante. À respeito, Antônio Jorge Silva, mais conhecido como Ió, presidente do Suzana, do bairro homônimo, exemplificou: “0 Cachoeirinha fazia uma festa e convidava o Suzana para uma Prova de Honra. No ano seguinte, o Suzana fazia a festa e chamava o Cachoeirinha para jogar na preliminar ou na Prova de Honra". 19

Essa troca de convites gerava a tendência de que equipes da mesma região ou com vínculos consolidados participassem com frequência das festividades das agremiações coirmãs. Contudo, a escolha do time que participaria da Prova de Honra sempre implicava em um cálculo que levava em conta, não apenas

\footnotetext{
${ }^{18}$ Cf. GEERTZ. Um jogo absorvente: notas sobre a briga de galo balinesa, p. 185-213.

${ }^{19}$ Entrevista de Antônio Jorge "ló" Silva concedida ao autor em 17 de junho de 2016.
} 
retribuições de chamados anteriores ou possíveis convocações futuras, mas a conjugação, por um lado, do prestígio que a celebração poderia ter no meio varzeano e, por outro, do risco de a equipe promotora ser derrotada pelo visitante. Fernando "Preto", dirigente e ex-jogador do Monte Azul, do bairro Esplanada, comentou em entrevista sobre a avaliação que se fazia: “... Aí pra prova de honra, a gente sempre convidava um time não muito forte, se não ganhava o troféu da gente, né. É o que faz hoje, todo o time faz é isso aí. A prova de honra é sempre, convida um time mais fraco, pra não perder o troféu bom né”. 20

A possibilidade de perder o principal troféu ofertado durante o festival representava um temor para os organizadores. Contudo, quanto maior o risco dessa subtração, ou seja, quanto mais renomada fosse a equipe visitante, mais absorvente tendia a se tornar a contenda, atraindo os olhares de outros participantes do meio varzeano, da imprensa, o que poderia conferir maior prestígio ao clube. Nessa perspectiva, o convite a equipes de base, como juniores de clubes profissionais, representava mecanismo de conquista de visibilidade e reconhecimento para os clubes, gerando grande interesse de público. Era a possibilidade dos atletas amadores medirem forças com aqueles de dispunham de estrutura reconhecida como de excelência, ainda que a probabilidade de derrota fosse quase certa. Jorgeval, ex-goleiro do São José Operário, do bairro Primeiro de Maio, rememorou a realização de um jogo do time do mesmo bairro contra equipe profissional:

Contra algum time de tradição... Eu não ia sempre, igual eu lembro de um que teve aqui no clube. 0 Flamenguinho jogou contra o time, tipo assim, sub-20 do América. Oh, um jogão cara, lotou o campo, trouxe o América aqui, né? Time profissional, mas vieram os meninos, é isso. ${ }^{21}$

Ao clube visitante, havia o desafio de "roubar" do adversário o objeto de desejo, o troféu da Prova de Honra. Essa possibilidade era altamente excitante e não implicava apenas em vencer o jogo, pois, não raras vezes, a derrota do time local era seguida de brigas e artimanhas para evitar que o prêmio fosse retirado do território. São fartos os relatos dos depoentes acerca de episódios desse tipo. Aqui,

${ }^{20}$ Entrevista de João Antônio "Ferrinho" Paranhos Leão e José Fernando "Preto" Pereira concedida ao autor em 15 de janeiro de 2017.

${ }^{21}$ Entrevista de Edval Gomes da Rocha e Jorgeval Costa Lima concedida ao autor em 08 de abril de 2017. 
são citados dois, que evidenciam estratégias diversas. Eliana, ex-dirigente do Avante, contou:

O Avante já saiu de campo com torcida debaixo de pedrada, os outros jogando pedra. [...] Ganhava o troféu no campo dos outros, (risos) e aí eles não queriam entregar troféu, aí era aquela briga, que não sei o que... E sempre tinha juiz da federação, né... Mas era bom demais porque a briga discorria, mas depois a gente vinha rindo no caminho. Era muito bom. ${ }^{22}$

Já José Pimenta, fundador do Riviera, do Alto Vera Cruz, rememorou outra artimanha dos derrotados: "Igual o troféu que eu falei com você que nós ganhamos no Primeiro de Maio, era um troféu desse tamanho assim, oh, só porque nós ganhamos o troféu eles trocaram o troféu. (risos) Sacanagem". ${ }^{23}$

Nessa medida, como ressalta Mauss, as reciprocidades não se baseiam apenas em troca de benesses entre os envolvidos, pressupõe, também, o que chama potlach ou prestações totais de tipo agonístico, em que rivalidades, baseadas no intuído de destruir as riquezas alheias, são verificadas.

\section{ESCOLHA DE PATRONOS, PADRINHOS E HOMENAGEADOS}

Talvez o momento do ritual que melhor evidencie as relações de reciprocidade presentes nos festivais se trate da escolha dos patronos, padrinhos e homenageados. Cada uma dessas figuras cumpre papel específico na comemoração e reitera laços que se mostram fundamentais para a manutenção das atividades regulares dos clubes. A apresentação pública, seja na divulgação dos programas, seja na encenação dos atos componentes da cerimônia, reiteram o desejo de consolidação, frente à comunidade e ao meio varzeano, dessas conexões.

Ao patrono ou patrona cabe a compra do troféu que será colocado em disputa durante cada uma das provas que compõe o festival. A expectativa dos organizadores é de que a premiação seja condizente com a importância da prova, cabendo à taça da Prova de Honra, ser a mais suntuosa, o que normalmente era medido pelo seu tamanho. Ao privilégio de serem convidados para partida de

\footnotetext{
${ }^{22}$ Entrevista de Maria da Conceição, Eliana e Carlos Pereira concedida ao autor em 10 de março de 2017.

${ }^{23}$ Entrevista de José Pimenta Gomes de Oliveira concedida ao autor em 8 de fevereiro de 2017.
} 
maior destaque, os membros das agremiações esperavam a retribuição de um objeto de maior valor.

A escolha do patrono estava baseada na expectativa da premiação que ele fosse capaz de oferecer. Isso não se restringia apenas à condição financeira do convidado, mas também ao valor que ele atribuía à agremiação e às relações que mantinha com ela ao longo do tempo. Muitos eram os casos em que a simpatia e a devoção ao clube eram fatores determinantes. Sobre essa escolha, José Pimenta do Riveira comentou:

Eu preferia colocar gente do bairro do que chamar os cara lá, porque você tem muita decepção, né, chamava para patrono um daqueles cara ricão lá, eles davam um troféu desse tamanhozinho assim, oh. Brincadeira! Na prova de honra? [...] Eu tinha essa teoria sabe? Preferia pôr um... Um pintor, um pedreiro, uma outra pessoa, do que por um... ${ }^{24}$

Em alguns casos, a oferta de um convidado de maior renome poderia ser decepcionante. Carlos Roberto Pimenta, o Fumê, relatou uma dessas ocasiões:

$\mathrm{Eu}$ me lembro, eu, com quinze, dezesseis anos, estava jogando no Terrestre, ali da Rua Itapecerica... que... chamava... hoje não pode falar favela, mas antigamente nós "falava", hoje é aglomerado, não é? É Buraco Quente. Aí, eu jogava lá, e nosso time era mais ou menos bom, aí nós fomos disputar um festival, lá no Anel Rodoviário, hoje Dom Cabral, contra o Pastoril, não esqueço disso. 0 patrono ou a patrona, era uma senhora, deve estar viva até hoje, da política, se você mexer seus... vai saber o nome dela, vai saber de onde é. Chamava-se Junia Marise, na época se não me engano ela era vereadora ou deputada, uma coisa assim... depois ela foi até coisa mais alta. Aí chegamos lá, estava aquele monte de troféu, assim, em cima da mesa, assim, né? Desde cedo eles põe os troféus em exposição, e nosso jogo era um dos últimos. Aí, fomos lá e tal... ganhamos o jogo de dois a zero, acabou o jogo e ela apareceu lá, a senhora, aí nos entregou uma medalha... que decepção (risos). [...] Que decepção... menino é complicado, e tudo favelado, com todo respeito, complicado demais... e o cara que comandava a gente, seu Pedrinho, gente boa demais, educado demais, querendo por um pano e nós todo mundo nervoso (risos). Tem umas coisas, velho, legal demais! ${ }^{25}$

Havia situações, inclusive, em que o convite significava a possibilidade de reconhecimento público da atuação do indivíduo, que era apresentado frente à comunidade como benfeitor da entidade, ainda que não dispusesse de condições

\footnotetext{
${ }^{24}$ Entrevista de José Pimenta Gomes de Oliveira concedida a Raphael Rajão Ribeiro em 8 de fevereiro de 2017.

${ }^{25}$ Entrevista de Carlos Roberto "Fumê" Pimenta concedida ao autor em 13 de maio de 2016.
} 
materiais para tal. Jorgeval, do São José Operário, ponderou sobre essas exceções: "Não era só por causa de poder aquisitivo, não. Às vezes o cara não tinha nada, mas nós até ajudávamos ele comprar um troféu só pra ele ser o patrono".26

Por mais que a princípio possa parecer algo menor, a eleição do padrinho da bola, ou da madrinha, como era mais recorrente, trata-se de posição bastante valorizada pelos membros do clube. José Pimenta, fundador do Riviera, comentou sobre as opções entre patronos e padrinhos:

Acabava o festival, o time tinha quatro, tinha seis, sete bolas. Porque cada padrinho, cada prova era um padrinho e um patrono. Aqueles caras mais "chegadão", tem um, usavam um termo assim, às vezes os caras falavam assim: "Eu quero dar um troféu do meu tamanho", eu pensava: "porque eu posso perder o troféu, a bola não, vou colocar ele pra ser padrinho, porque ele dar um troféu do tamanho dele, disputava a gente perde e aí?", entendeu? ${ }^{27}$

Uma vez que o equipamento esportivo ofertado era de grande valia, dada as dificuldades financeiras para se custear sua aquisição regular, ao longo do ano. Como explicou Expedito, ex-presidente da Ferroviária:

A bola, madrinha da bola, normalmente a bola era uma mulher, era madrinha da bola. Então, era outra coisa difícil era você comprar uma bola, na época lá da G18, porque ela vinha com dezoito gomos, era rara. Hoje não, hoje cada clube tem cinco, seis bolas, é uma coisa banal. As coisas antes eram muito custosas. ${ }^{28}$

Os festivais constituíam-se, nessa medida, em oportunidade de angariar fundos e materiais para a manutenção das atividades cotidianas da entidade.

A definição dos homenageados seguia lógica inversa, já que era forma de o clube realizar contraprestação àqueles que ao longo do ano tivessem dado alguma ajuda ou mecanismo para constituir novas alianças e angariar possíveis fiadores políticos ou patrocinadores. Era comum que figuras do mundo político, da imprensa e do campo esportivo assumissem esse papel, especialmente durantes as provas principais. Tratava-se de ocasião de reconhecer a atuação de pessoas que

\footnotetext{
${ }^{26}$ Entrevista de Edval Gomes da Rocha e Jorgeval Costa Lima concedida ao autor em 8 de abril de 2017.

${ }^{27}$ Entrevista de José Pimenta Gomes de Oliveira concedida ao autor em 8 de fevereiro de 2017.

${ }^{28}$ Entrevista de Raimundo Expedito Fernandes concedida ao autor em 20 de janeiro de 2017.
} 
viabilizaram as atividades do clube durante o ano, como ressaltou Expedito, expresidente da Ferroviária:

Não, às vezes, você convidava um diretor do DFA, era, isso era normal. 0 Edimar, por exemplo, diretor do DFA, sempre foi homenageado pela Ferroviária. O Vinicius que foi diretor do DFA, o doutor Bregunci, o Elmer Guilherme, sempre nos ajudou. Sempre foram pessoas assim muito gratas, que a gente devia obrigação, nos ajudava. Às vezes, porque antigamente, você pra conseguir um alvará você tinha que pagar, então, através de meios você conseguia um advogado uma coisa qualquer, você conseguia... Porque tinha que estar com a documentação toda em dia, tudo certinho, às vezes faltava alguma coisa você dependia de uma lei, essas... Você sempre teve essa ajuda. Então você homenageava essas pessoas no festival, e a pessoa se sentia bem, gratificada. ${ }^{29}$

Essas deferências constituíam-se em importante estratégia de sobrevivência dos clubes, articulando-se com relações clientelistas que garantiam, inclusive, a dispensa de compromissos dos campeonatos oficiais, para promoção do seu festival, a exemplo daquela que fora negada ao Renascença. 0 programa do festival do Inconfidência (fig. 2), por exemplo, encontra-se em meio à documentação do Departamento de Futebol Amador da Federação Mineira de Futebol, pois seguiu anexo ao convite para participação de seus diretores na condição de homenageados.

A seleção, contudo, não se restringia a pessoas externas à comunidade. Especialmente nos jogos iniciais, de menor projeção, abria-se oportunidade para homenagens a membros da comunidade, muitos dos quais prestaram serviços à agremiação. Era ocasião, ainda, para laurear os mais velhos que compartilhavam da estima e do respeito dos moradores do lugar.

Durante a realização do festival, todas essas relações podiam ser dramatizadas e apresentadas ao público, em ritos como a entrada em campo, os discursos, o pontapé inicial e a entrega dos troféus. Era recorrente a destinação de espaços de destaque para os homenageados, seja nas tribunas de honra, das quais alguns campos dispunham, ou em palanques especialmente montados para a celebração. Assim, como destaca Mauss, havia grande clareza dos envolvidos sobre as obrigações que deles se esperavam quando tais convites eram realizados, constituindo esses em verdadeiras convocações. Expedito relatou em sua

\footnotetext{
${ }^{29}$ Entrevista de Raimundo Expedito Fernandes concedida ao autor em 20 de janeiro de 2017.
} 
entrevista de que forma os convites eram aceitos, reforçando a ideia de que eram sempre aceitos:

A gente perguntava assim, chegava perto da pessoa, abordava ela: "Aqui nós vamos ter um festival dia tal, e nós estamos procurando um padrinho para o jogo tal, você tem condição de...". Convidava, fazia o convite antes, pra ver se a pessoa tinha condições de comprar um troféu e participar na data né. E sempre era aceito. ${ }^{30}$

\section{Eleição da Rainha e das Princesas}

Rainhas e princesas eram duas personagens que estiveram presentes em boa parte dos festivais varzeanos. Seu papel no ritual consistia, principalmente, em atuar durante a Prova de Honra, quando era apresentada ao público pelos capitães dos times, a quem, terminada a disputada, entregaria o troféu principal da celebração, ou ainda, ingressava em campo junto com outros, como se vê no caso do festival do Alvorada, do bairro Nova Gameleira (fig. 6). Em caso de bailes de gala, poderiam ainda participar, de forma que fossem coroadas durante a noite dançante, como foi o caso da comemoração pelo 19o aniversário do Santa Maria (fig. 3).

0 processo de escolha da rainha e das princesas variava de clube para clube. Em alguns casos, tratava-se de simples eleição por parte dos diretores da agremiação, a qual levava em conta basicamente laços de parentesco, com a escolha de filhas e sobrinhas. Algo fundamental, nesse caso, era a possibilidade dos familiares arcarem com os custos de confecção da indumentária ostentada pela selecionada.

Outro mecanismo utilizado era a criação de júri, normalmente formado por membros da diretoria dos clubes, que faziam eleição baseada em critérios de beleza e simpatia. Nesses casos, em regra, caberia ao clube ofertar vestido que pudesse ser usado pela escolhida. Atualmente, observa-se a realização de concursos para a escolha de musas de times amadores, bem como de torneios que compõe o circuito varzeano.

${ }^{30}$ Entrevista de Raimundo Expedito Fernandes concedida ao autor em 20 de janeiro de 2017. 


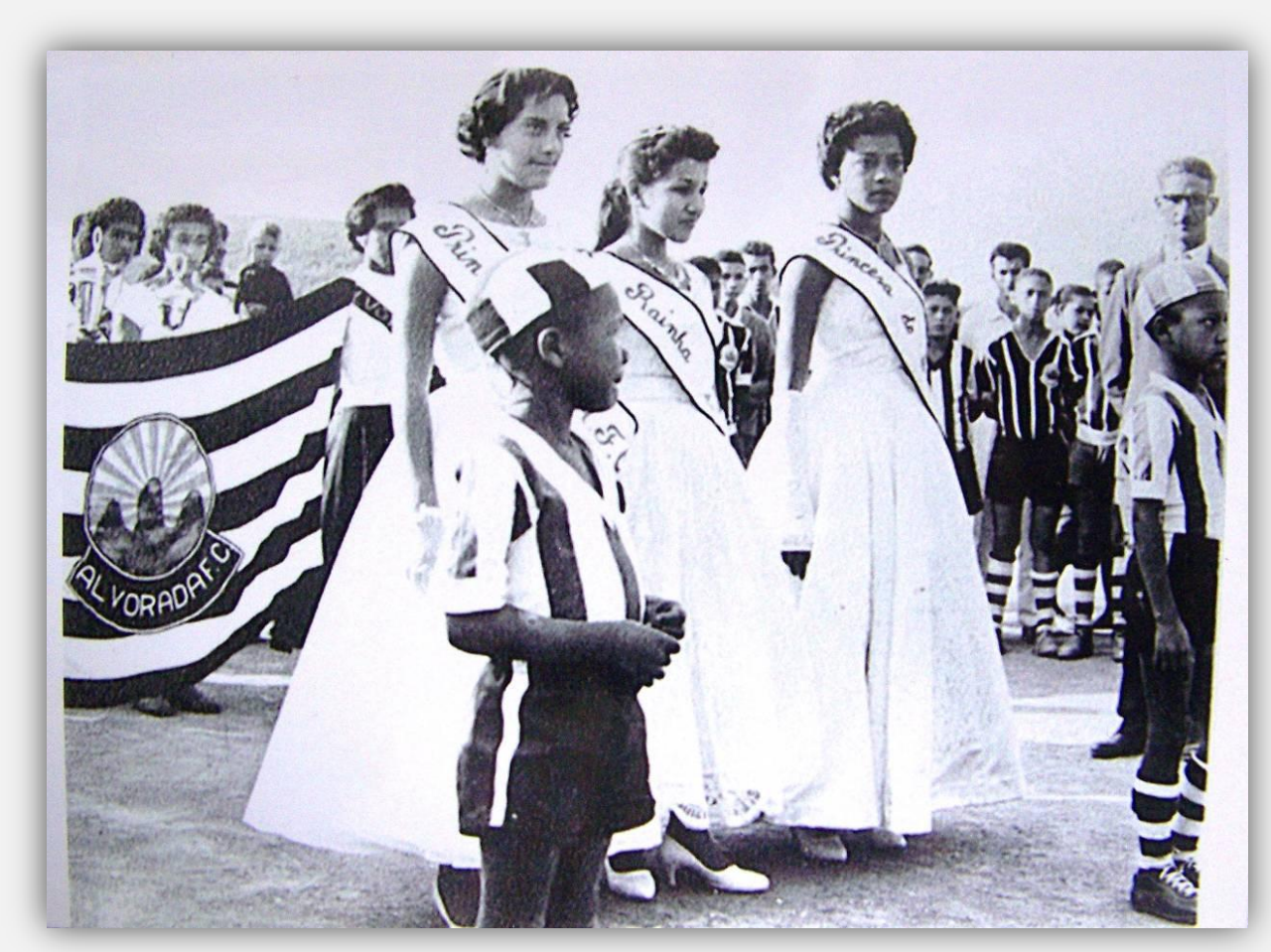

Fig. 6: Entrada em campo durante festival do Alvorada Futebol Clube, anos 1950. Acervo Nilton "Chapinha" Graciano da Silva.

Contudo, a forma mais regular de escolha da rainha e das princesas era por meio da venda de cotas pelas garotas, sendo que aquela que fosse mais bem sucedida era a escolhida. Como se recordou Eliana, do Avante:

Vender, igual tinha rainha de pipoca e amendoim, rei do amendoim, rainha da pipoca, a gente vendia, tinham os talõezinhos né, e a gente vendia, quem vendesse mais era a rainha. Aí depois quando eu deixei de ser a rainha, fui rainha uns quatro ou cinco anos seguidos. Depois disso eu passei pra essa menina que mora aqui do lado, que agora é evangélica né, não pode nem tocar no assunto, mas (risos) ela foi rainha no meu lugar, certo, aí nós compramos vestido pra ela arrumamos tudo direitinho pra ela ser rainha, ela foi. Depois dela foi a Junia, e aí parou por aí. ${ }^{31}$

Os recursos angariados pelas participantes eram revertidos ao clube promotor do festival, o que viabilizava a preparação da celebração e a aquisição de materiais esportivos. Novamente, observa-se a retribuição, com a contraprestação em forma do reconhecimento público da garota como rainha ou princesa do festival, ocupando lugar de destaque na comemoração.

\footnotetext{
${ }^{31}$ Entrevista de Maria da Conceição, Eliana e Carlos Pereira concedida ao autor em 10 de março de 2017.
} 


\section{ARRECADAÇÃo DE FUNDOS E PREPARAÇÃo DA EQUIPE PARA O FESTIVAL}

A organização dos festivais era forma do clube reformar vínculos comunitários. Reconhecidamente aquele era um evento que gozava de grande interesse entre os habitantes dos bairros periféricos da capital mineira. Sobre a movimentação em dias de festival, José Isaac, fundador do São Luiz da Vila Ventosa, relatou que:

No campo lá em cima lá, se você chegasse depois de três horas, você não via o jogo, você não via o jogo, né compadre? Enchia demais. Você tinha que passar no meio para ver o jogo, você podia entrar nos barracos aqui, porque a favela já estava formada, você podia entrar num barraco aqui, tomar banho, trocar de roupa, e tudo (risos) não tinha ninguém dentro de casa, não tinha ninguém, o pessoal ia tudo para o campo. Porque dava prazer você ver o time do São Luiz jogar. Porque o time do São Luiz, o time era bom, quando não era filiado. ${ }^{32}$

Com vistas à promoção do festival, os clubes criavam diversas estratégias para arrecadação de fundos, sendo a mais comum a venda de rifas. Os valores angariados permitiam que a agremiação pudesse comprar seus uniformes. Como marca da passagem que essa celebração significava, aquele era momento de se apresentar ao público com vestuário renovado. Expedito falou em entrevista sobre a produção de novos materiais para os festivais:

O problema mais caro sempre é a arbitragem, você tem que estar comprando o material e normalmente sempre o festival você... Mantém... lança um material novo. Como é que você vai entrar num festival, que é aniversário do seu time com material usado? Que é uma das coisas... Hoje não, hoje qualquer político joga pela janela material, antigamente não, você tinha que ir... Era na casa de esportes João Delones que era a mais tradicional dentro de Belo Horizonte, que era na Rua Caetés com Bahia ali, e mandava fazer um timbre, quem bordava os escudos, era tudo um complicador, hoje não, na maquina ali tece. ${ }^{33}$

Do ponto de vista econômico, o festival também representava oportunidade para a comunidade local que, graças à boa afluência de público ao lugar, podia gerar renda adicional, comercializando toda sorte de comidas e bebidas aos espectadores das partidas. A presença desses ambulantes, ou mesmo a montagem de barraquinhas em torno do campo, é muito forte na memória social acerca do tema.

\footnotetext{
${ }^{32}$ Entrevista com Elias, João e José Isaac concedida ao autor em 19 de fevereiro de 2017.

${ }^{33}$ Entrevista de Raimundo Expedito Fernandes concedida ao autor em 20 de janeiro de 2017.
} 
Outro fator importante que justificava a arrecadação trata-se da contratação de árbitros para as partidas, sendo que sua presença variava de acordo com a importância da prova, uma vez que esse era um dos maiores custos para a promoção do festival. Assim, havia desde os convidados para os jogos das categorias menores, os chamados "juízes de barranco", que apitavam gratuitamente e sem o auxílio de bandeirinhas, até os trios remunerados, ligados à Federação Mineira de Futebol, para a condução das Provas de Honra.

\section{DivULGAÇÃo DO PROGRAMA}

A realização do festival pressupunha a mobilização e publicização da festa, para o que as entidades criavam estratégias para viabilizar a produção de material de divulgação, bem como articulavam alianças que fossem capazes de amplificar a notícia do evento. Não eram raros programas que trouxessem a divulgação de uma série de patrocinadores, especialmente, estabelecimentos comerciais de bairro, a exemplo do que evidencia o programa da comemoração do 37으 aniversário do Suzana (fig. 7). A distribuição das peças gráficas mobilizava as demais equipes convidadas para compor a celebração. Expedito explicou, em sua entrevista, de que forma se fazia a divulgação da programação:

Porque na época, quando a Ferroviária ou qualquer time ia fazer um festival, a gente colocava aquele cartaz, porque era normal, não sei se você conhece, cartaz de festival. Festival da Ferroviária vinha os times que iam jogar, então a gente dava dez, doze cartazes, pra aqueles times que eram convidados, e eles espalhavam nos bairros deles também. Por isso é que vinha muito público. Cada time que ia jogar no festival trazia seu próprio público. ${ }^{34}$

Nessa medida, novas relações de reciprocidade se davam. Um dos principais objetivos dos realizadores era garantir que o campo estive o mais cheio possível. A grande afluência de público representava sinal de prestígio do clube, o que repercutia no meio varzeano.

\footnotetext{
${ }^{34}$ Entrevista de Raimundo Expedito Fernandes concedida ao autor em 20 de janeiro de 2017.
} 


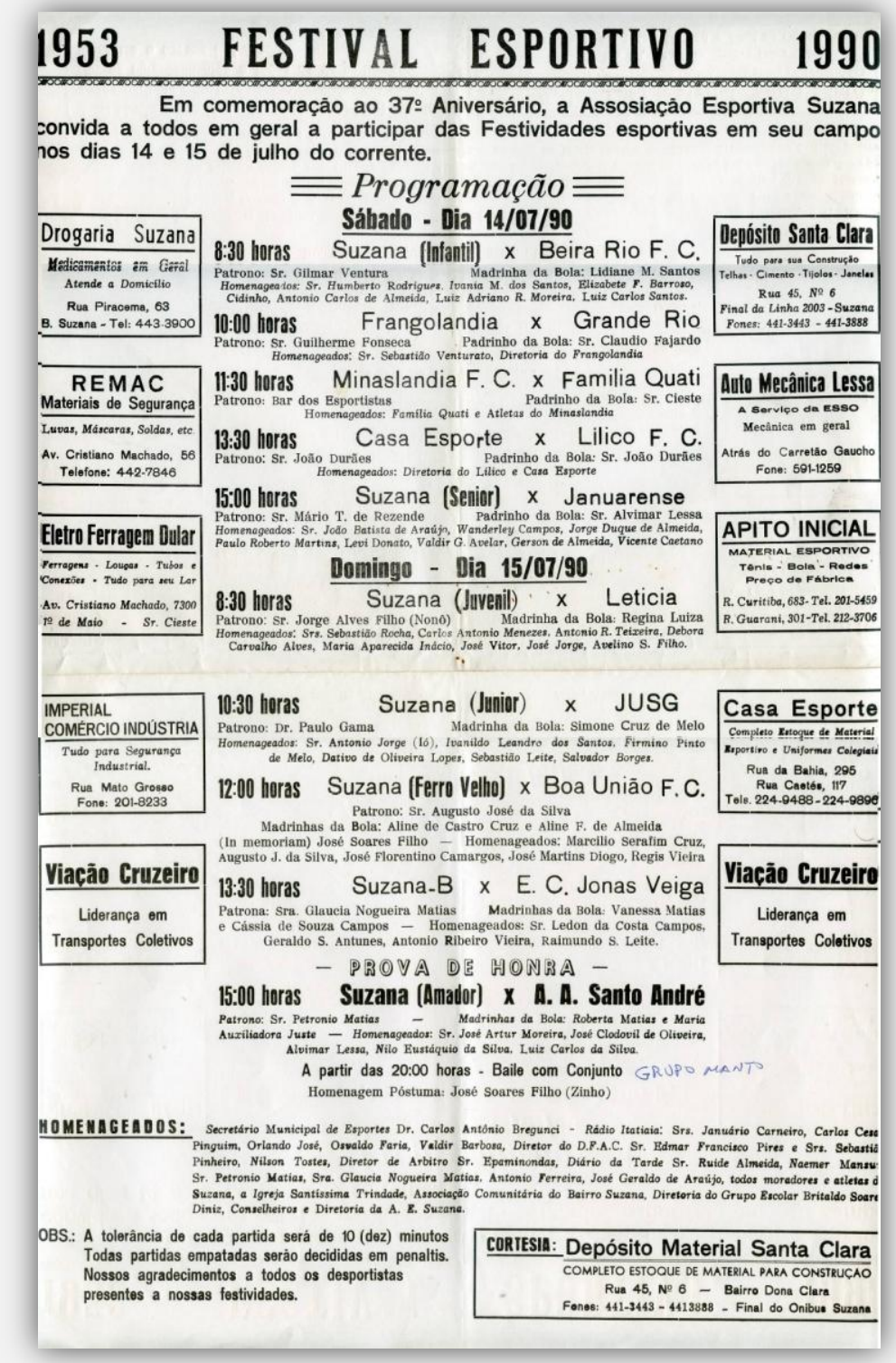

Fig. 7: Programa do festival em comemoração ao $37^{\circ}$ aniversário da Associação Esportiva Suzana, 1990. Acervo Antônio Jorge "ló" Silva.

\section{PREPARAÇÃo E DECORAÇÃo do CAMPO}

Dia de festival era ocasião para produção de decoração especial para o campo. Era principalmente no domingo que a área era recoberta por todos os adereços exigidos. As bandeirolas, presas em barbantes e espalhadas por todo o campo eram o elemento mais recorrente. Outro bastante comum eram os bambus, com os quais se formavam arcos, que criavam espécie de portal pelo qual times, patronos, madrinhas e rainhas adentravam o local da partida. A exemplo de outros rituais, a preparação 
do lugar era momento fundamental. A alvorada convocava a comunidade para finalização dos preparativos. Rocha, presidente do São José Operário, relembra-se da convocação para preparação do campo em dia de festival: “A gente que era menino e jogava na época do infantil, ele falava: 'Oh, na hora do jogo vocês tem que vir pra cá mais cedo pra gente poder fincar os bambu, amarrar as bandeirinhas'. Então, assim, era ajuda mútua do time, entendeu?"35

Era na produção dos itens decorativos que o envolvimento da população local ficava mais claro. Grandes grupos atuavam, nas semanas que antecediam os festivais, para garantir a produção dos adereços. Enquanto uns empreendiam a busca de bambus pela vizinhança, outros se dedicavam à confecção de bandeirinhas. Expedito tratou em sua entrevista da mobilização para produção dos adereços utilizados na decoração do campo:

Tinha que fazer uai. Mas... É uma decoração meio rustica, não era difícil. Você tinha, por exemplo, hoje aqui na cidade é difícil achar um bambuzal, e o bambu é o mais bonito dos enfeites. Porque você chegava no campo nas laterais ali no alambrado e enchia de bambu, então você... Ficava uma coisa rustica, bacana. E ali naquele bambu, você vinha com uns bambulinhos de cor, tipo uma rabiola de papagaio e vinha tecendo aquilo ali pra ficar colorido, pra chamar atenção, vinha com as bandeirinhas... A gente ficava aqui oh, na rua, semanas e semanas comprando o barbante, cortava o papel e fazia aquelas bandeirolas colando com grude. ${ }^{36}$

Aos clubes convidados cabia a entrega de suas bandeiras na véspera da celebração. Essas seriam ostentadas em cada uma das partidas, marcando e visibilizando a presença das instituições que se engajavam na comemoração. Sobre a colocação das bandeiras dos times participantes, Eliana, do Avante, comentou em sua entrevista:

O Avante pedia pra trazer, pra poder colocar, pedia pra trazer na véspera porque no sábado a gente já arrumava né, então colocava. Igual tinha em Copa do Mundo que tem as bandeiras de cada seleção. Então punha lá de todo mundo que ia jogar no... todos que vão jogar, né? Independente da hora... ${ }^{37}$

${ }^{35}$ Entrevista de Edval Gomes da Rocha e Jorgeval Costa Lima concedida ao autor em 8 de abril de 2017.

${ }^{36}$ Entrevista de Raimundo Expedito Fernandes concedida ao autor em 20 de janeiro de 2017.

${ }^{37}$ Entrevista de Maria da Conceição, Eliana e Carlos Pereira concedida ao autor em 10 de março de 2017. 
Em algumas ocasiões, o hasteamento poderia se revestir de solenidade, incluindo-se a execução do hino nacional, como evidencia foto do festival do Alvorada (fig. 8).

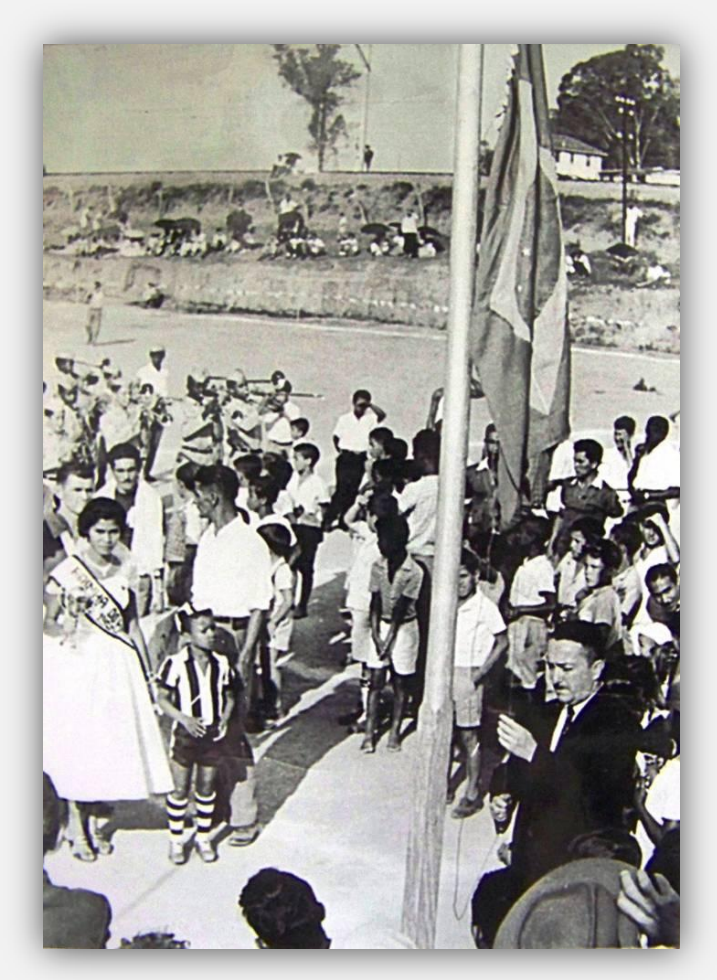

Fig. 8: Hasteamento da bandeira durante festival do Alvorada Futebol Clube, anos 1950. Acervo Nilton "Chapinha" Graciano da Silva.

\section{CONSIDERAÇõES FINAIS}

Práticas recorrentes no futebol de várzea de Belo Horizonte e de outras cidades brasileiras, os festivais esportivos mais do que meras comemorações de mais um aniversário do clube, constituíam-se em cerimônias plenas de simbologias, momento no qual inúmeros vínculos que perpassavam o cotidiano das agremiações eram renovados. Grande número de atores sociais era mobilizado na dramatização que se dava ao longo do fim de semana no qual a celebração transcorria, representando relações comunitárias, políticas e esportivas forjadas pelas entidades.

Em diversos contextos a promoção de um grande festival, poderia significar distinção igual ou maior à conquista de um campeonato. Não é a toa que essas 
celebrações ocupam espaço tão privilegiado na memória social que se tem sobre essa prática esportiva e cultural. A recorrência com que o tema surge nos relatos dos depoentes que vivenciaram essa atividade é revelador da centralidade que o ritual tinha na organização das agremiações varzeanas. ${ }^{38}$

Neste breve texto, procurou-se apontar os elementos mais gerais da estrutura dos festivais. Em especial, as relações de reciprocidade reiteradas pelo cerimonial envolvido. Diversas outras interpretações se fazem possíveis, a partir do momento em que se examinam mais detidamente cada um dos ritos e dos símbolos que são neles mobilizados. Contudo, essa se trata de tarefa para outro momento.

Hoje, alguns clubes ainda tentam manter a tradição dos festivais. Contudo, no caso belo-horizontino, não se observa a mesma adesão social do passado, sendo a promoção dessas festividades tarefa de dirigentes que vivenciaram o período áureo dessas celebrações e que julgam importante realiza-las em datas especiais, tal qual a passagem dos 80 anos do Alvorada. 0 desuso dessa prática, no entanto, não significa a decadência do futebol de várzea, já que outras formas de estruturação tem emergido com força, tal qual a realização de torneios regionais. Disputados em paralelo aos campeonatos do circuito oficial, tem se mostrado capazes de reativar velhas rivalidades, mobilizar apoio da comunidade e de comerciantes locais e proporcionar um clima descontraído de competição, tal como se relata acerca dos saudosos festivais.

\section{Referências}

BOURDIEU, Pierre. A Linguagem Autorizada: As Condições Sociais da Eficácia do Discurso Ritual; Os Ritos de Instituição. In: A economia das trocas simbólicas: o que falar quer dizer. São Paulo: Editora da Universidade de São Paulo, 2008, p. 85-106.

DARTON, Robert. História e Antropologia. In: DARTON, Robert. 0 beijo de lamourette. São Paulo: Companhia das Letras, 1990, p. 284-303.

\footnotetext{
${ }^{38}$ Como destacou Carlos Pereira, presidente do Avante: "Tinha muitos troféus de festivais né, porque antigamente o grande, o glamour do futebol não era nem campeonato, era mais festival, o pessoal abria mão de disputar o campeonato..." Entrevista de Maria da Conceição, Eliana e Carlos Pereira concedida ao autor em 10 de março de 2017.
} 
GEERTZ, Clifford. A interpretação das culturas. Rio de Janeiro: Guanabara, 1989.

MAUSS, Marcel. Ensaio sobre a dádiva: Forma e razão da troca nas sociedades arcaicas. In:

Cosac Naify, 2003, p. 183-314. . Sociologia e Antropologia. São Paulo,

MELO, Victor Andrade de (org.) Os sports e as cidades brasileiras: transição dos séculos XIX e XX. Rio de Janeiro: Apicuri, 2010.

RIBEIRO, Raphael Rajão. A bola, as ruas alinhadas e a uma poeira infernal: os primeiros anos do futebol em Belo Horizonte (1904-1921). Rio de Janeiro: Drible de Letra/Multifoco, 2018.

SEGALEN, Martine. Ritos e rituais contemporâneos. Rio de Janeiro: Editora FGV, 2002.

SOUZA, Jhonatan Uewerton. A "Candidatura Sportiva" e outras aproximações entre esporte e política na Curitiba da Primeira República. Vozes, Pretérito \& Devir, UFPI, Teresina, PI, Dossiê Temático "História dos esportes", ano VI, v. 5, n. 1, 2016, p. 126.

Recebido para publicação em: 12 out. 2018. Aprovado em: 21 mar. 2019. 